\title{
Lopramine の脳波学的研究
}

\author{
渡辺 繁紀, 川崎 博已, 植木 昭和 \\ 九州大学薬学部薬理学教室* \\ (昭和50年11月27日[特])
}

\begin{abstract}
要的：慢性電極植込みウサギを用いて, lopramine の脑波作用を imipramine， amitriptyline と比較検討した，Lopramine は自発脳波に対して，皮質および扁桃核では高篃圧徐波，海馬 では $\theta$ 波の脱同期化をひき抗こし，いわゆる drowsy pattern を惹起した. Imipramine， amitriptyline も同様に自発脳波を drowsy pattern 化するが，その作用は lopramine 上りも はるかに強い，また imipramine や amitriptyline では動物に行動上鎮静を示し，軽度の筋 弛縟，歩行失調をおこすのに対して， lopramine ではごく軽度の鎮静を示すのみであった。 Lopramine は音刺激および中脳䋧梯体，視床内側中心核，後部視㦿下部の電気刺激による脳 波覚醒反応に対してほよんど作用を示さないが，imipramine，amitriptyline はこれらの反応

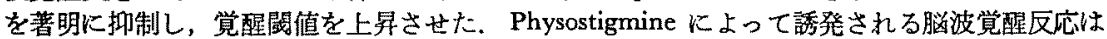
lopramine によってほとんど影響されなかったが， imipramine，amitriptyline はこの覚醒反 応を抑制し，持続時間は短縮した。視床内側中心核刺激による漸增反応は lopramine によっ て全く変化せず， imipramine，amitriptyline によっては增強される傾向を示した，海馬，屚 桃核の電気刺激による大脳边縁杂後発射は lopramine によってほとんぞ影響を受けなかった が， imipramine，amitriptyline では投与初期に著明に抑制，その後增強という2相性の作用 が認められた，以上，lopramine は自発脑波の drowsy pattern 化を扰こす点で，imipramine， amitriptyline と類似しているが，その作用ははるかに弱く，譄幹網侎体賦活系など覚醒系に 対する抑制作用がほとんど認められず，恋た大脑辺縁系後発射に対する作用もほとんどないな ぞ，その脳波作用は imipramine や amitriptyline とかなり異った新しい型の抗らつ剤である。
\end{abstract}

緒言

Lopramine hydrochloride はスエーデンの Leo 社で開発された新しい向精神薬である. 化学的には N-methyl-N-(4'-chlorophenacyl)-3-(10, 11-dihydro-5H-dibenz (b,f)-azepin-5yl)-propylamine hydrochloride で, imipramine に類似した三環性構造を有する化合物である (Fig. 1). 臨床的にも imipramine などの三環性抗う つ骽に似た効果が認められて3)，動物実験においても in vivo および in vitro のいずれでも noradrenaline の re-uptake 阻害や noradrenaline の作用堌強を抗こす作用がみられている4,5). 教室に括ける行動薬理学的研究の

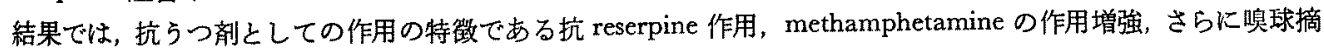
出ラットの mouse-killing behavior の抑制作用などを有することがわかっている6).しかし， lopramine の脳波 作用に関する報告はほとんどない，そこで著者らは lopramineの脳波作用につき，三環性抗らつ剤 imipramine および amitriptyline のそれと比較㭘討し，その脳内作用機構の特徽を明らかにせひと本実験を企てた。

媨波の测定は，動物の行動観察と平行してできるように慢性電極植迟み法によって無麻酔，無拘束の状態で 行った．また脳波作用は自発脳波だけでなく，音刺激や中脳網様体，視床内側中心核。後部視床下部刺激による 脑波覚醒反応, 潮增反応, さらに大脳辺縁系後発射に対する作用についても㛟討した。

\section{実験材料ならびに実験方法}

\section{1. 実呀動物}

体重 $2.5 \sim 3.5 \mathrm{~kg}$ の雄性白色ウサギ合計35羽を使用した。

\footnotetext{
* 812 福岡市東区馬出3-1-1
} 


\section{CHEMICAL STRUCTURES}

\section{LOPRAMINE}

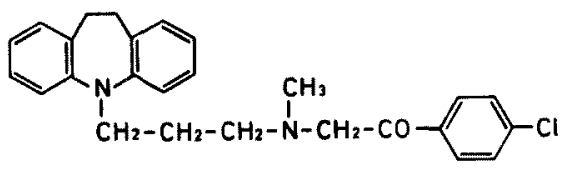

IMIPRAMINE

AMITRIPTYLINE
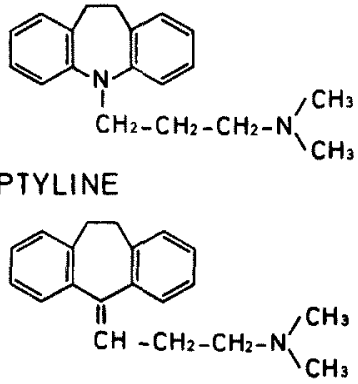

Fig. 1. Chemical structures of tricyclic antidepressants.

\section{2. 慢性電極の植込み手術}

Pentobarbital-Na $40 \mathrm{mg} / \mathrm{kg}$ の腹腔内注射麻醉のもとに，動物の頭部を脳定位固定装置（東大媨研型）に固

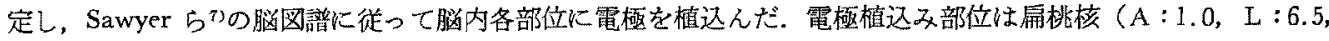
$H:-5)$ ，背側海馬 $(A:-3, L: 5, H: 5)$, 視床内側中心核 $(A:-3, L: 1, H:-5)$, 中脳網様体 (A: -8，L：3，H：-3) である. 電極は直径 $0.2 \mathrm{~mm}$ の絶縁ステンレス・スチール線でつくった双極電極で, 先 端部を $0.5 \mathrm{~mm}$ の長さだけ絶縁を除去し，両極間の距離は $0.5 \sim 1 \mathrm{~mm}$ とした。また脳波の誘道にす電気刺激 にも同一の電極を使用し，先端部絶縁を $1 \mathrm{~mm}$ 程度除去して前頭葉 (frontal cortex) および 後頭葉 (occipital cortex）の硬膜下皮質表面に密着するように植込んだ．各電極は頭蓋骨の穿孔部に愾科用セメントで固定したの ち，それぞれコネタターソケットの足に一本ずつハンダ付けし，ソケットそのものも，あらかじめ頭蓋骨にたて たネ゙シ針とともにセメントで固定し，電極敊よびンタットのハンダ付け部分の露出したところはすべてセメント で被った，手術終了後，手術部位には希ヨードチンキを叙布し，また術後 3 日間は毎日一回プロカインペニシリ ンG（武田薬品）10万草位を筋注した，なお一匹の動物については，脳波誘導および刺激電極を含めて 6 ケ所の 脳部位にそれぞれ適当な組合せで植込むようにした。

\section{3. 脳波測定ならびに脑内電気刺激}

電極植达み手術後 2 週間以上経過して，手術創が完全に治瘾し，安定した脳波が 記録出来るよらになった 後，本实験を行った，怔物を無麻醉のもとにシールドケース内に備えた小さな箱に入れ，頭部だけを外に出して おく，頭部ソケットにリード線を連結して脳波記録を行った。な拈，薬物投与後は必要に心じて動物を固定箱か ら出してその行動を観察した，実駼中，シールドケースは黒色のカーテンで被い内部を暗くした，脳波はポリグ ラフ (PG602，三举測器製）を用いて双極誘導で記録した．脳内電気刺激には，電子管刺激装置（MSE40，日本 光䉓製）を用い，脳波覚醒反応を測定するための視床内側中心核，後部視床下部，中脳網様体刺激には $100 \mathrm{~Hz}$, パルスウ $0.1 \sim 0.2 \mathrm{msec}, 1 \sim 10 \mathrm{~V}$ の矩形波を用い，刺激時間は 5 秒間とした，漸增反応の実験では，視床内側 中心核に $8 \mathrm{~Hz}, 0.1 \mathrm{msec}, 2 \sim 10 \mathrm{~V}$ の刺激を10秒間加古九．音刺激には，音・光刺激装置 (MS-2PS, 日本光電 製) を使用し，2,000 Hz の monotone を5 秒間与えた。

大脳辺緑系の後発射実駼は，渡辺ら ${ }^{8}$ の力法に従い，海馬あるいは扁桃核に $50 \mathrm{~Hz}, 0.2 \sim 1.0 \mathrm{msec}, 1 \sim 8 \mathrm{~V}$ の矩形波を 5 秒間加えた。 また反復後発射をおこさせる場合には少くとる刺激間隔を10分間以上あけるよ5にし た。 


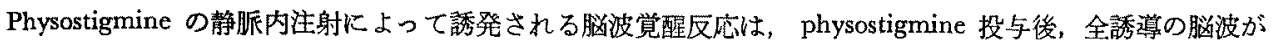
arousal pattern を示し始めるまでの時間 (覚酻反応発現時間) と，覚霍波が消失して drowsy pattern が連続し て出現するよらになるまでの覚醒反応持綕時間を測定した，薬物の作用を調べる場合には，被検薬物投与 5 分後

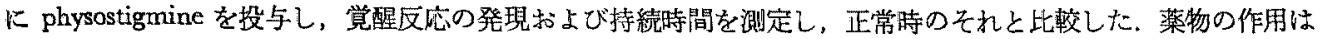
4〜8 例について得られた覚醒反応の発現時間执よび持綕時間の平均値を算出し，薬物投与後の変化について統 計学的な检討を行った。正常群との有意差検討に流 student's t-test な用いた。

\section{4. 組轿学的模索}

実験終了後，脳内各部位の植込欢電極に $3 \mathrm{~mA}$ の直流通電を 10 秒間加えた缕，1\%フェロシアン化カリウ

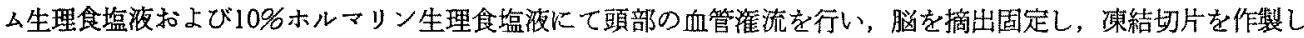
て各電極の局在を組織学的に確認した。

\section{5. 使用薬物}

実験に使用した薬物は， lopramine hydrochloride (第一製楽から提出された純末），imipramine hydrochlo-

PABBIT

FC $1 /$ Hath

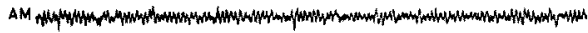

A

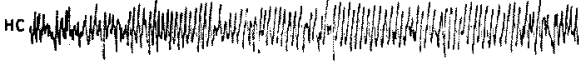

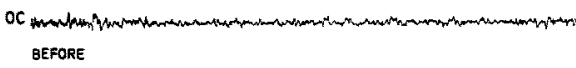

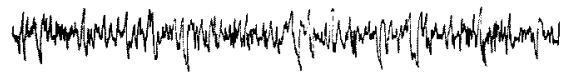

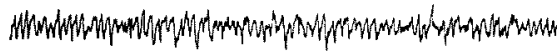

B

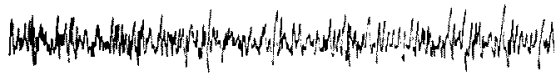

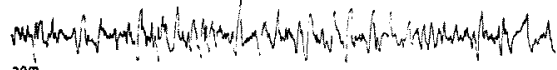
$20 \mathrm{~m}$

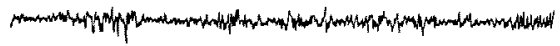

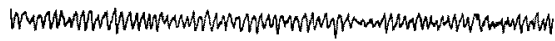

c

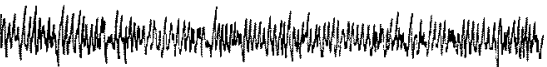

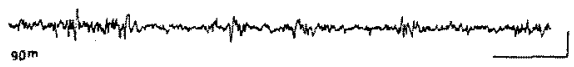

Fig. 2. Effect of lopramine on spontaneous EEG activity in the rabbit. A: control EEG. B: 20 min after i.v. injection of lopramine $20 \mathrm{mg} / \mathrm{kg}$. C: after $120 \mathrm{~min}$. FC: frontal cortex, AM: amygdala, HC: dorsal hippocampus, OC: occipital cortex. The vertical scale indicates $200 \mu \mathrm{V}$ and the horizontal scale $3 \mathrm{sec}$, at the right hand bottom of panel C. Abbreviations and scales are the same for all figures.

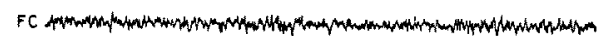

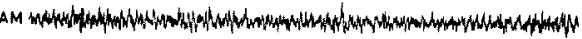

A HC

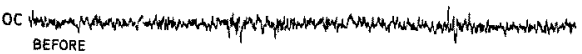

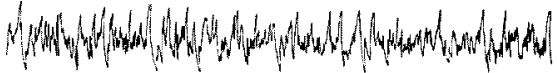

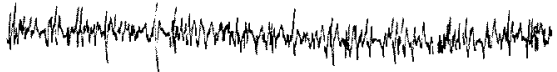

B

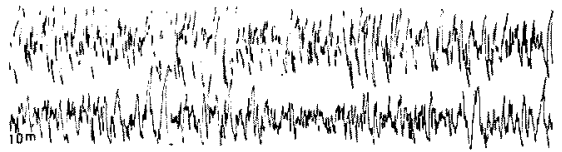

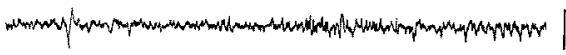

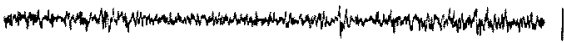
C

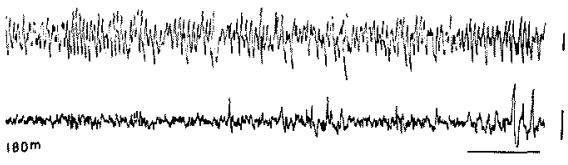

Fig. 3. Effect of imipramine on spontaneous EEG activity in the rabbit. A: control EEG. B: 10 min after i.v. injection of imipramine $5 \mathrm{mg} / \mathrm{kg}$. C: after $180 \mathrm{~min}$. 
ride (トフラニール注射液, 藤沢)，amitriptyline hydrochloride (トリプタノール注射液，万有)，physostigmine salicylate (純末，MERK) である. Lopramine は用時 propylene glycol に溶解し，投与量がつねに $0.1 \mathrm{ml} / \mathrm{kg}$ となるよう調整した。 また対照として同量の propylene glycol 投与による作用む確認した。䒚物はすべて耳

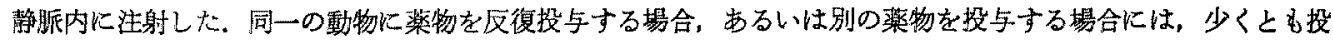
与間隔を 5 日間以上あけた。

\section{実 験 成 績}

\section{1. 自発䐉波におよぼす影曋}

慢性電極を植込んだウサギ15羽を用いて，自発脳波におよぼす lopramine の影溜を imipramine, amitriptyline のそれと比較した。

ウサギをシールドケース内の箱に入れて脳波を测定すると，はじめは皮質，揙桃核では低電王速波，海馬で

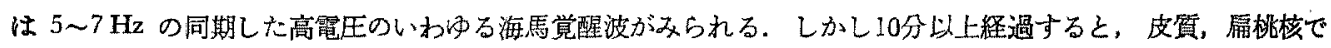
は高電王徐波成分が増加し，同時に海馬觉酉星波の同期がくずれて不覞則になり，全体的にいわゆる傾眠パターン (drowsy pattern) を示寸時期が多くなる。この場合でも外部から整微な刺激を加えると，脳波は容易に覚醒パタ

RABEII

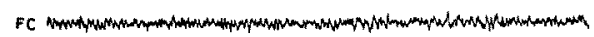
AM

A

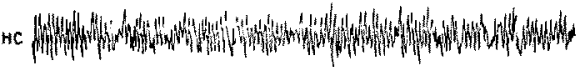

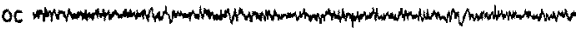
MEFORE

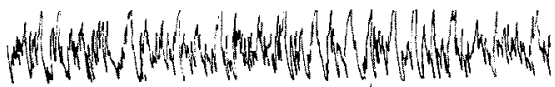

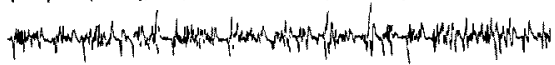

$\mathbf{B}$

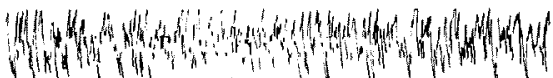

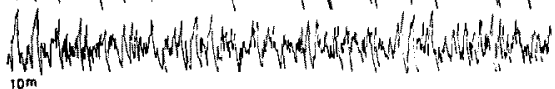

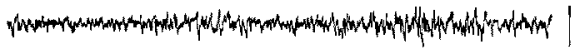

C

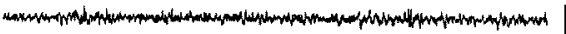

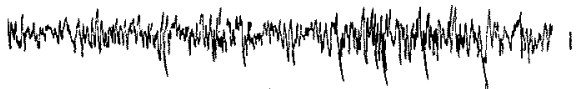

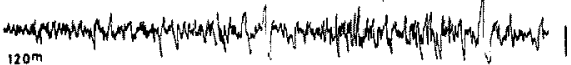

Fig. 4. Effect of amitriptyline on spontaneous EEG activity in the rabbit. A: control EEG. $B$ : $10 \mathrm{~min}$ after $\mathrm{i}, \mathrm{v}$, injection of amitriptyline $2 \mathrm{mg} / \mathrm{kg}$. C: after $120 \mathrm{~min}$.
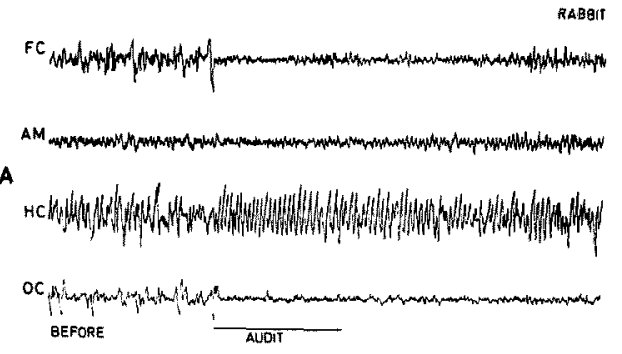

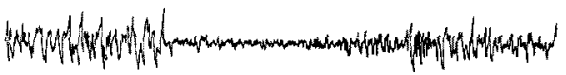

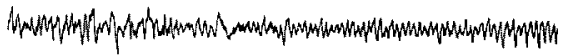

B
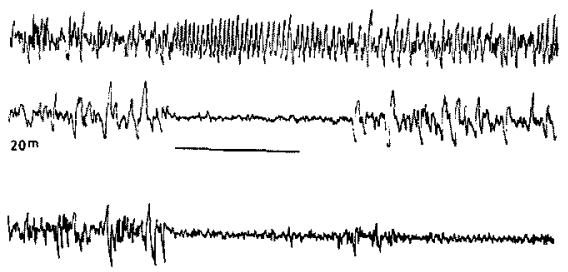

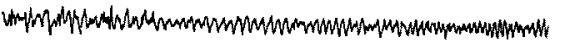

C

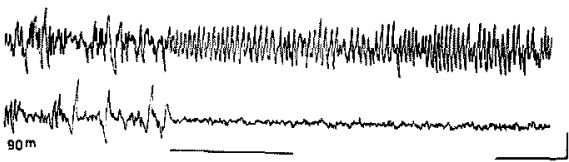

Fig. 5. Effect of lopramine on EEG arousal response to auditory stimulation in the rabbit. A: control response. B: $20 \mathrm{~min}$ after i.v. injection of lopramine $20 \mathrm{mg} / \mathrm{kg}$. C: after $90 \mathrm{~min}$. Auditory stimulation was applied at the point indicated by a horizontal line. 
ーン (arousal pattern) に変わる.

Lopramine の作用は，のべ12羽のウサギを用いて調べた，Lopramine $5 \mathrm{mg} / \mathrm{kg}$ を耳静脈内に投与しても， 行動上にも脳波上にも著明な变化は認められないが，10 mg/kg の投与では，注射後数分より皮質には高電压徐

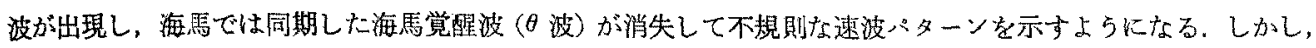
その程度は軽度であった， $20 \mathrm{mg} / \mathrm{kg}$ の投与では，脳波の傾眼パターンはかなり著明となった。しかし，かかる 脳波変化を示している時でも，行動上ウサギは軽度の鎮静状態を示すの及で，筋弛綏や運動失調は認められなか った. この様な脳波の変化は40〜90分後には结は正常に復した〈Fig. 2).

Imipramine の作用は，のべ8 羽のウサギを用いて調べた．Imipramine $2 \sim 5 \mathrm{mg} / \mathrm{kg}$ を静注すると， 2 分後 頃より，皮質脳波は高電圧徐波，海馬では同期した $\theta$ 波がくずれて不規則なパターンに変った，阴桃核の脳波に は投与直後，とくに著明ではないが高電圧速波が出現した。これは数分も経過すると消失して，高電压徐波パタ ーンに変った．この時期にウサギを箱から出して行動を観察すると，整度の筋弛緩および歩行に際しての運動失 調か認められた。このような脳波および行動の变化は 3〜4時間後には洼ば正常に復した (Fig. 3).

Amitriptyline の作用は，のべ 8 羽のウサギを用いて調べた．Amitriptyline 1〜2 mg/kg の投与では，静注： 直後から皮質脳波は著明な高電圧徐波を示し，海馬では $\theta$ 波の同期がくずれて不規則なパターンとなった，碬桃

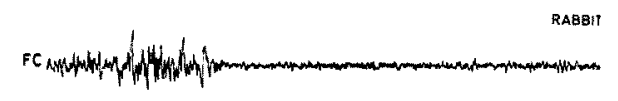

A
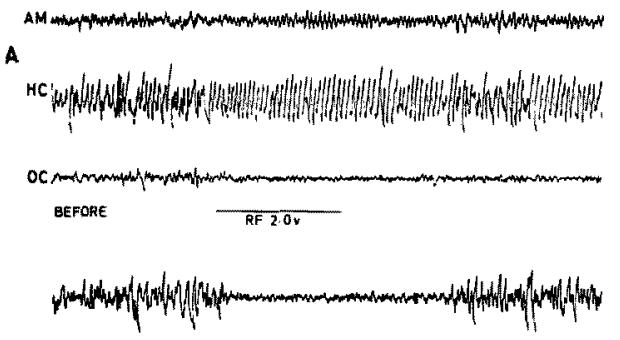

B

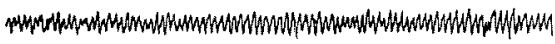

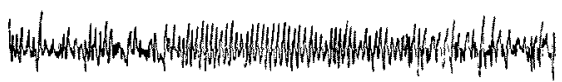

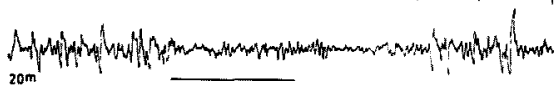

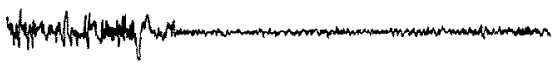

$c$

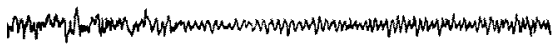

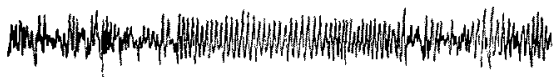

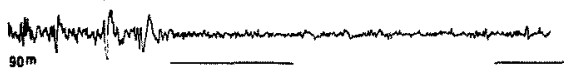

Fig. 6. Effect of lopramine on EEG arousal response to mesencephalic reticular stimulation in the rabbit. A: control response. B: $20 \mathrm{~min}$ after i.v. injection lopramine $20 \mathrm{mg} / \mathrm{kg}$. C: after $90 \mathrm{~min}$. The mesencephalic reticular formation was stimulated electrically $(100 \mathrm{~Hz}, 0.1 \mathrm{msec}, 2.0 \mathrm{~V})$ at the point indicated by a horizontal line.

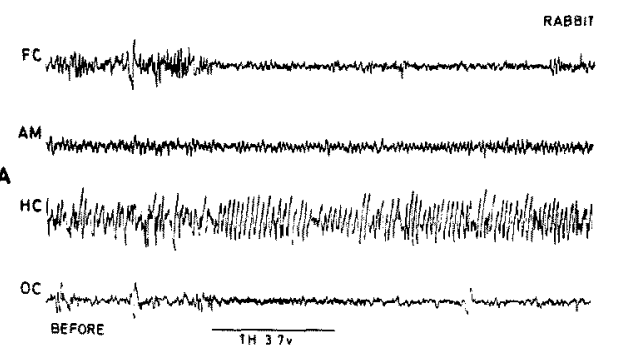

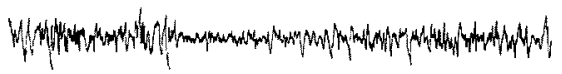

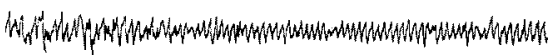

B

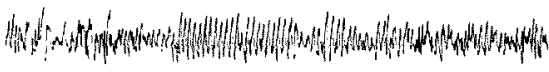
Pom

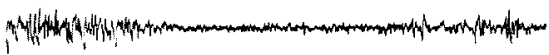

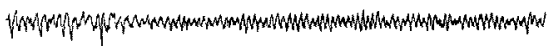

c

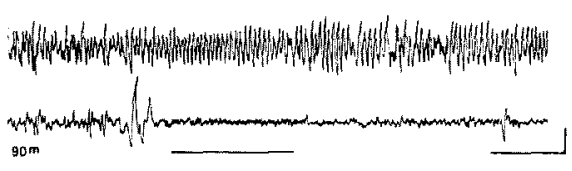

Fig. 7. Effect of lopramine on EEG arousal response to centromedian thalamic stimulation in the rabbit. A: control response. B: 20 min after i.v. injection of lopramine $20 \mathrm{mg} / \mathrm{kg}$. C: after $90 \mathrm{~min}$. The centromedian thalmus was stimulated electrically $(100 \mathrm{~Hz}, 0.1 \mathrm{msec}, 3.7 \mathrm{~V})$ at the point indicated by a horizontal line. 
㤥の脳波は imipramine の場合と同様に投与初期に高電圧速波が出現した後，高電圧徐波となった．この場合，

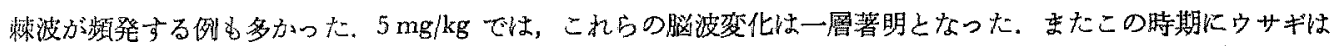
軽度の筋弛緩と運動失調を示した，脳波掞上び行動に対するこれらの作用は，1〜2 $\mathrm{mg} / \mathrm{kg}$ では $2 \approx 3$ 時間後， $5 \mathrm{mg} / \mathrm{kg}$ では 4〜5時間持続した後，添ぼ正常に復した (Fig. 4).

以上, lopramine の自発脳波に対寸る作用は，imipramine，amitriptyline 上りむはるかに弱く，その作用強 度は imipramineの約 $1 / 10$ ，amitriptyline の約 $1 / 20$ 程度と考えられ，竞たその持続むはるかに短かかった。

\section{2. 脳波觉醒反応におよぼす影響}

音刺激ならびに視床内側中心核，中脳網様体，後部視㦿下部の電気刺激によって誘発される脳波覚醒反応に 対する lopramine の作用をウサギ15羽について調べ， imipramine 拉よび amitriptylineの作用と比較検討した。 刺潡の強度は薬物投与前に每回確実に一定の反応が得られる電生を選んで実蹒を行った，

ウサキが行動上安静状態にあり，皮質脳波が高電圧徐波，海馬では規則正しい海馬覚型波の同期がくずれて 不規則となったいわゆる drowsy pattern を示す時期に音刺激を加克ると，皮質および扁桃核の脳波は直ちに低 電压速波となり，海馬の脳波は高電化の同期した $\theta$ 波に変わり，いわゆる脳波覚醒反応 (EEG arousal response)

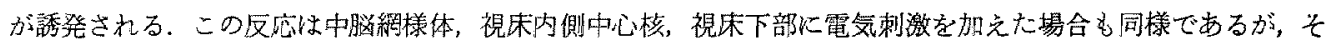
れは音刺激の場合よりも一層著明であり，反応の持続も長い，正常時においては，いずれの刺激に上る覚醒反応 も刺激终了後数分間は持続する。

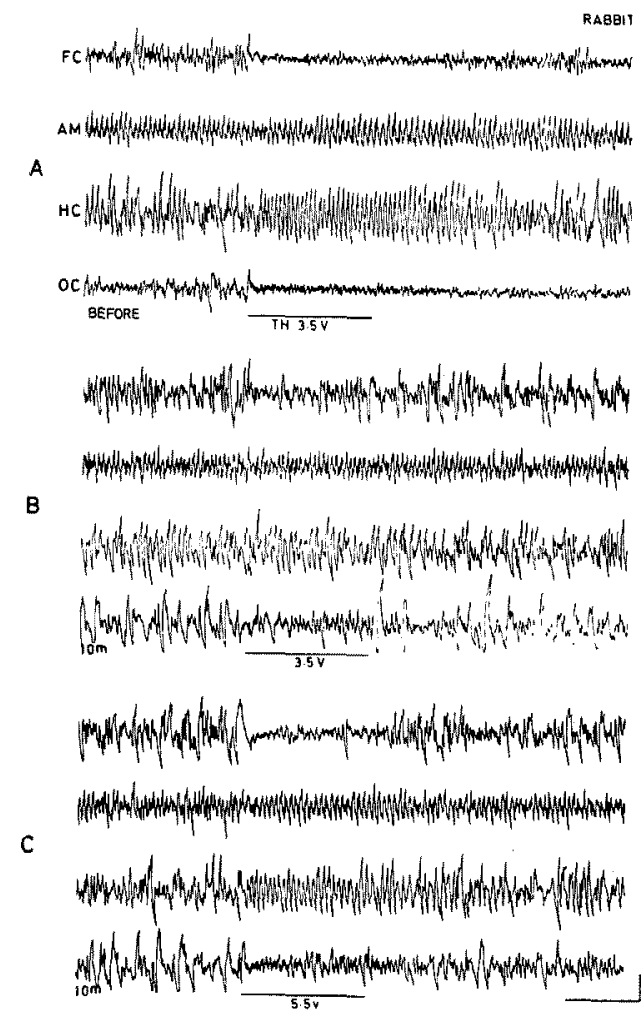

Fig. 8. Effect of imipramine on EEG arousal response to centromedian thalamic stimulation in the rabbit. A: control response. B: $10 \mathrm{~min}$ after i.v. injection of imipramine $5 \mathrm{mg} / \mathrm{kg}$, the centromedian thalamus was stimulated electrically $(100 \mathrm{~Hz}, 0.1 \mathrm{msec}$, $3.5 \mathrm{~V}$ ) at the point indicated by a horizontal line. C; 10 min after drug administration, the stimulus voltage was increased to $5.5 \mathrm{~V}$. 


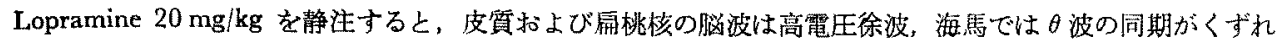

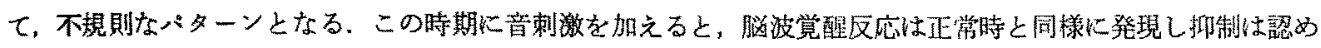

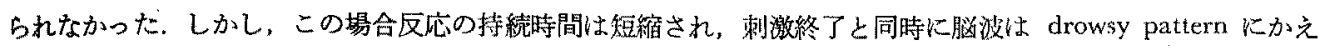

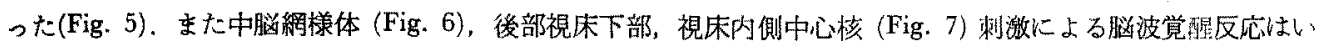

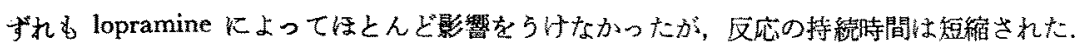

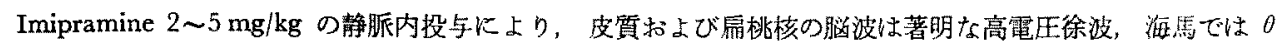

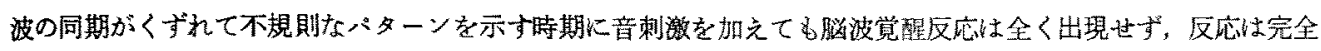

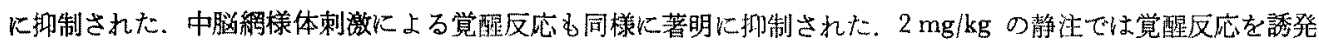

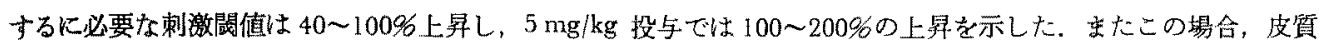

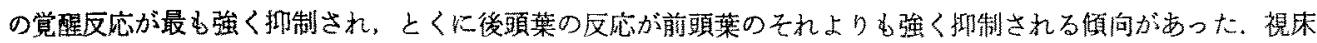

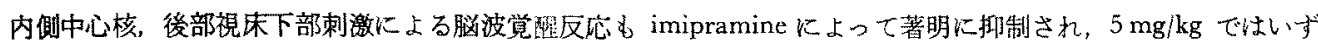
れの刺激でるその刺激閶值は80\%以上の上界を示した (Fig. 8).

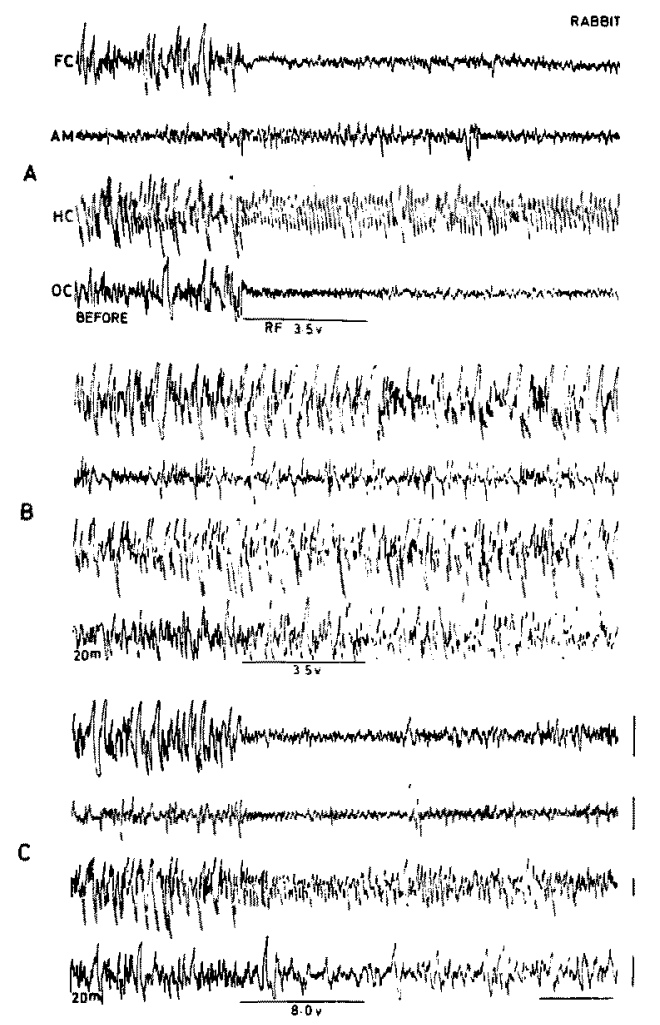

Fig. 9. Effect of amitriptyline on EEG arousal response to mesencephalic reticular stimulation in the rabbit. A: control response. B: $20 \mathrm{~min}$ after i.v. injection of amitripty. line $2 \mathrm{mg} / \mathrm{kg}$, the mesencephalic reticular formation was stimulated electrically (100 $\mathrm{Hz}, 0.1 \mathrm{msec}, 3.5 \mathrm{~V}$ ) at the point indicated by a horizontal line. $C$ : 20 min after the drug administration, the stimulus voltage was increased to $8.0 \mathrm{~V}$.

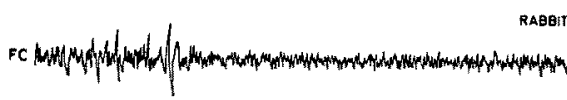

AM raw

A

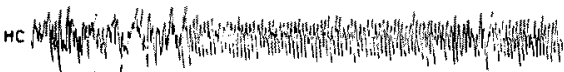

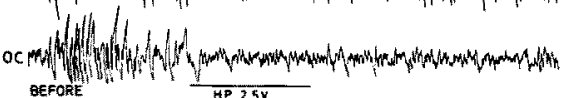

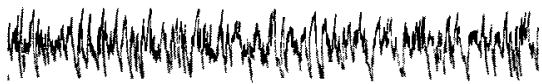

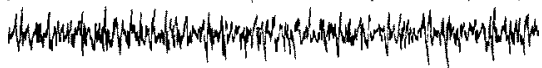

B

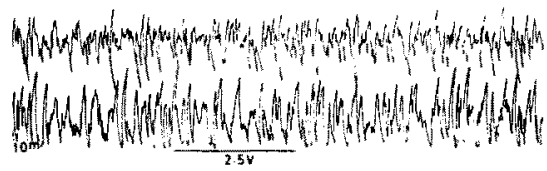

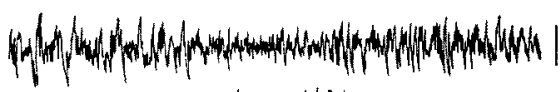

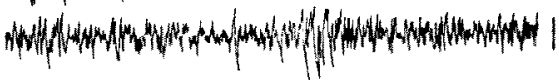

c

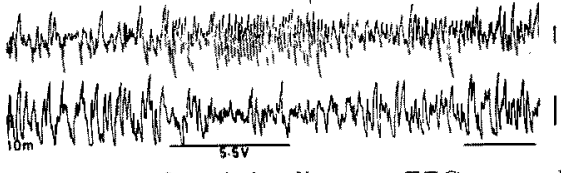

Fig. 10. Effect of amitriptyline on EEG arousal response to posterior hypothalamic stimulation in the rabbit. A: control response. B: $10 \mathrm{~min}$ after $i . v$, injection of amitriptyline $5 \mathrm{mg} / \mathrm{kg}$, the posterior hypothalamus was stimulated electrically $(100 \mathrm{~Hz}, 0.1$ msec, $2.5 \mathrm{~V}$ ) at the point indicated by a horizontal line. $C: 10 \mathrm{~min}$ after the drug administration, the stimulus voltage was increased to $5.5 \mathrm{~V}$. 
Amitriptyline 2〜5 mg/kg の投与時の作用むimipramine の場合と注ぼ同様で，音刺激，中脳網様体，視床 内側中心核，後部視床下部のいずれの刺激による脳波覚醒反応も著明に抑制され，その作用は imipramine のそ れよりもさらに強力であった。测澈閥值は $2 \mathrm{mg} / \mathrm{kg}$ の静注ではいずれの部位でも $80 \%$ 以上， $5 \mathrm{mg} / \mathrm{kg}$ では150\%

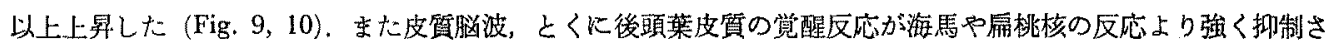
れる㑯向も imipramine の場合と同様であった.

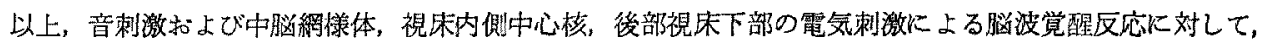

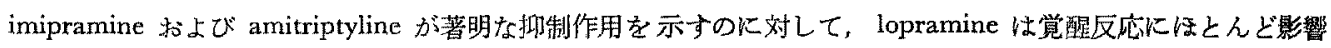
をおよばさなかった。

\section{Physostigmine によって誘発される脳波觉醒反応におよばす影製}

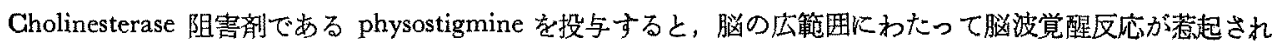
る9).この脳波覚醒反応の発現および持続時間に战よぼす lopramine, imipramine, amitriptyline の作用をウサ ギのべ30羽を用いて調べた。まず16羽のウサギを用いて physostigmine の静脈内注射による正常時の脳波覚醒反 応の発現就よび持続時間を記録測定し，これを対照とした。これに対する薬物の影響を謂べる第合には，被検薬 物を静注して 5 分後に physostigmine 学静注し，脳波覚醕反応の発現および持続時間を湘定して対照の反応と比 慗した。

Physostigmine $0.1 \mathrm{mg} / \mathrm{kg}$ を静注すると，1〜2分後頃から，皮質䍁波は著明な低電王速波を示すようにな る.この変化は後頭葉よりる前頭葉においてより速やかに現われるのが普通であった，海馬には高電圧の著明に 同期した $\theta$ 波が出現し，これは音刺激や中脳給様体電気刺激による覚醒反応出現㭙に舅察されるものより，もっ

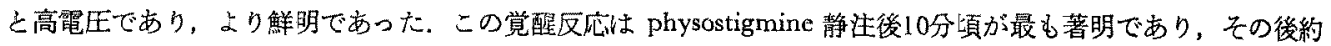

RABB!I

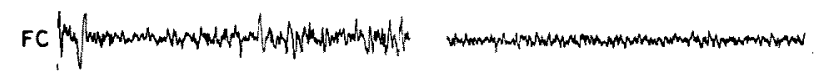

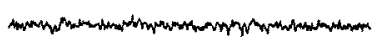

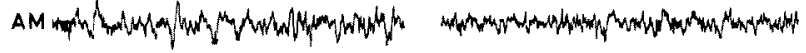

A

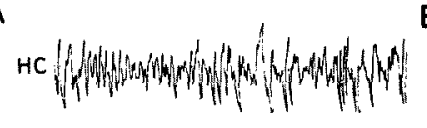

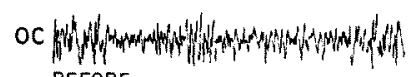
BEFORE
B

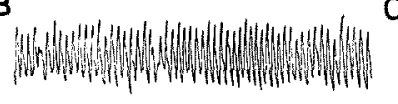

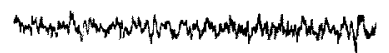

C

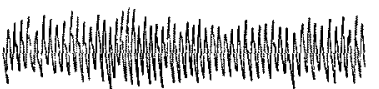

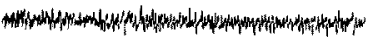
$5 \mathrm{~m}$

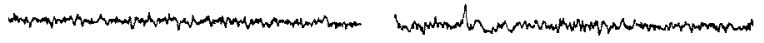

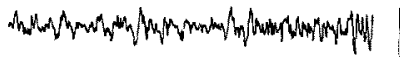

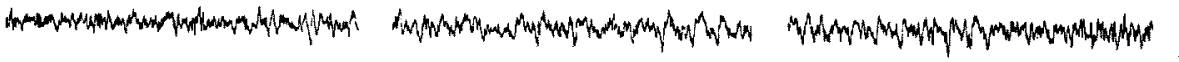

D

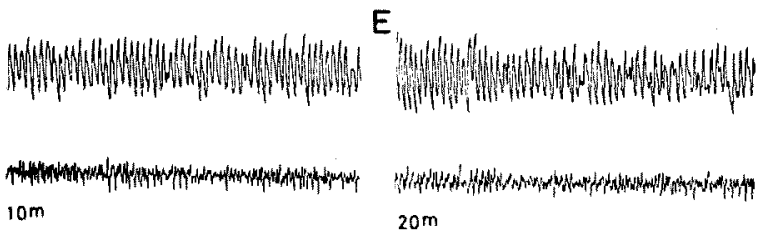

$F$
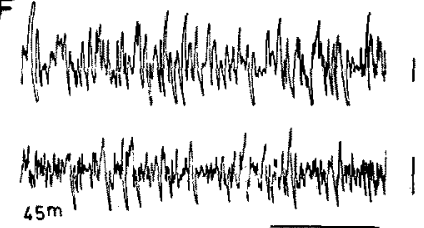

Fig. 11. EEG arousal respose induced by physostigmine in the rabbit. A: control EEG. B: $2 \mathrm{~min}$ after i.v. injection of physostigmine $0.1 \mathrm{mg} / \mathrm{kg}$. C: after $5 \mathrm{~min}$. D: after 10 min. E: after $20 \mathrm{~min}$. F: after $45 \mathrm{~min}$. 
40分間にわたってほとんど変化することなく覚䝀パターンが持続した，覚醒反応が消失する際には，まず後頭葉 に徐波成分が出現し，ついで前頭葉や扁桃核にも徐波が現われる上ら妉り，同時に海馬の規則正しい $\theta$ 波の同 期がくずれ，次第に全般的な drowsy pattern k移行するようになる (Fig. 11)。この上5に脳波が全誘導にわ たって drowsy pattern を示すよらになった時点を覚酷反応終了とみなした. Physostigmine 投与後。このよう

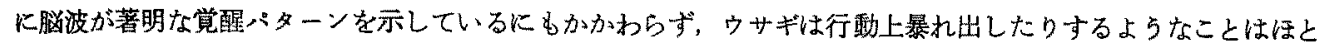
んどなく，脳波の変化は必らずしも行動上の変化と平行しない上うであった．Physostigmine $0.2 \mathrm{mg} / \mathrm{kg}$ の静注 でも覚醖反応はその持続が延長するだけで，その程度は活とんど同じであった。

16 羽のウサギで榆討した結果，physostigmine $0.1 \mathrm{mg} / \mathrm{kg}$ 単独投与による正常時の脳波覚醍反沁は，発現時 間平均1.8土0.4分，持続時間は平均 $36.3 \pm 8.6$ 分であった。

この覚醒反応に対する lopramine $20 \mathrm{mg} / \mathrm{kg}$ 投与の作用は 6 羽のウサギを用いて検討した．Lopramine 20 $\mathrm{mg} / \mathrm{kg}$ を静注すると，皮質および扁桃核の脳波は高電王徐波，海馬で $\theta$ 波の同期がくずれて不規則となる，5

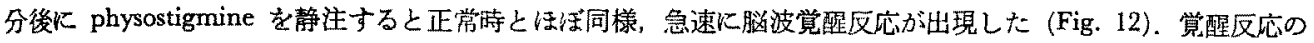
発現時間は $1.8 \pm 0.4$ 分，持続時間は $38.2 \pm 3.1$ 分となり，正常時とほとんど差はなかった，またこの場合，出現 した覚醒反応のパターンも正常時と同様,きわめて鮮明なるのであった。

Imipramine 2 および $5 \mathrm{mg} / \mathrm{kg}$ の作用は14羽のウサギを用いて調べた. Imipramine 投与後には，physosti-

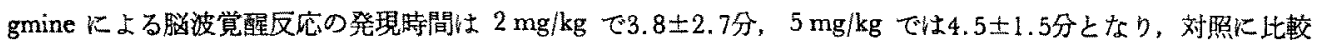

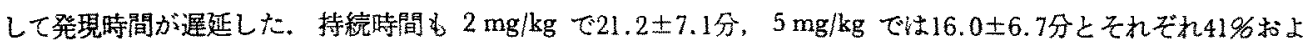
び56\%短縮し，対照との間に0.5\%の危険率で有意差が認められた，な拉この場合，発見した覚醒波パターンも 正常時のそれとはかなり異なり，海馬では規則正しく同期した $\theta$ 波が長く持続することが少なく，しばしば不規

RABEIT
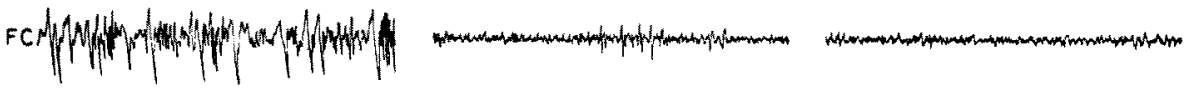

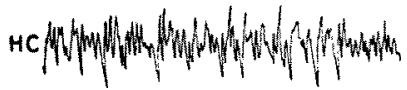

A

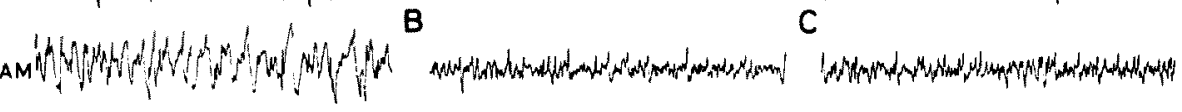

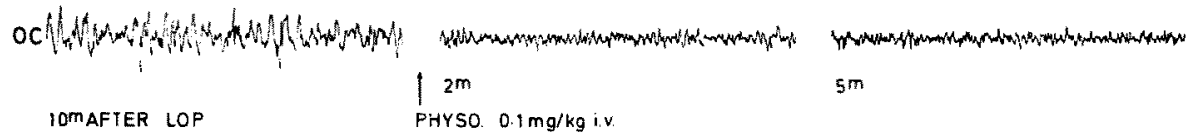

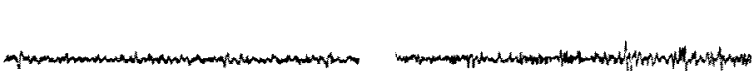

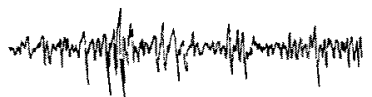
HWy.

D

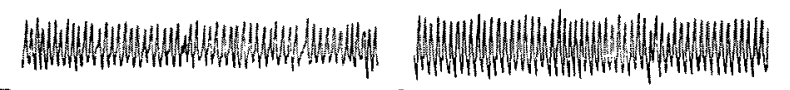

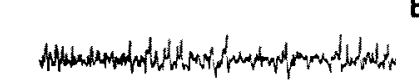

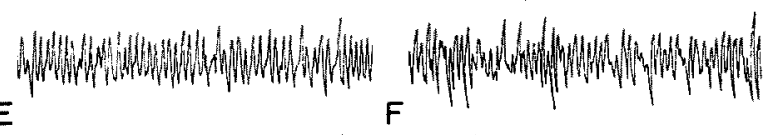
(

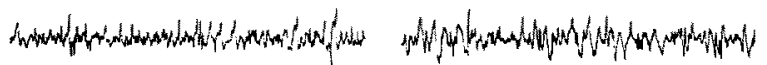

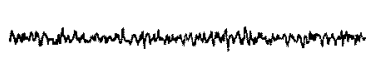
$10 \mathrm{~m}$

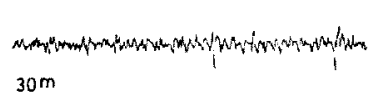
$30 \mathrm{~m}$

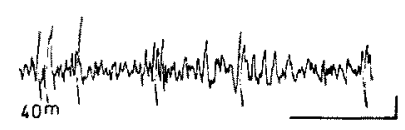

Fig. 12. Effect of lopramine on EEG arousal response induced by physostigmine in the rabbit. A: EEG after i.v. injection of lopramine $20 \mathrm{mg} / \mathrm{kg}$. B: 2 min after i.v. injection of physostigmine $0.1 \mathrm{mg} / \mathrm{kg}$. C: after $5 \mathrm{~min}$. D: after $10 \mathrm{~min}$. E: after $30 \mathrm{~min}$. F: after $40 \mathrm{~min}$. Lopramine was administered $5 \mathrm{~min}$ before physostigmine injection. 


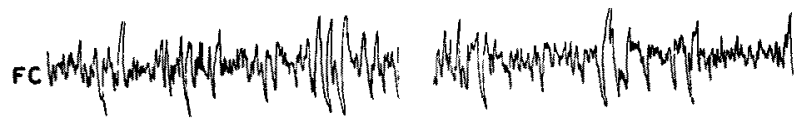

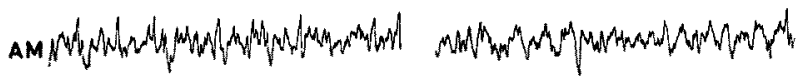

A $B$

C

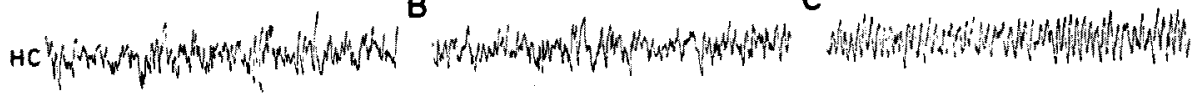

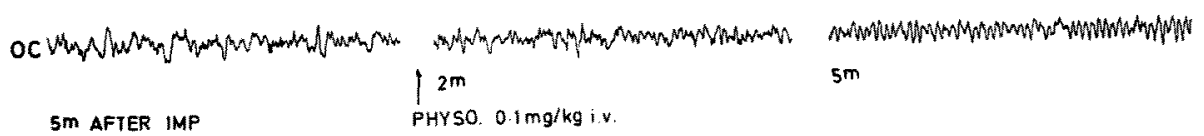

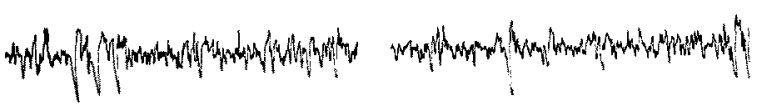

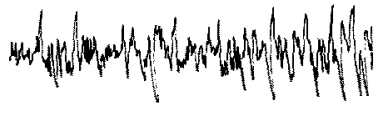

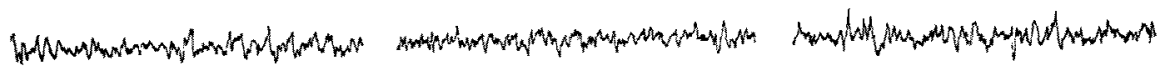
D

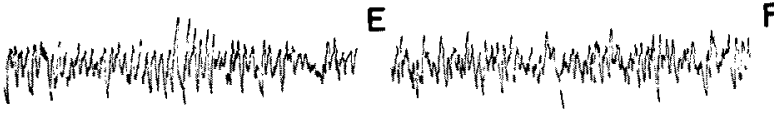
F.

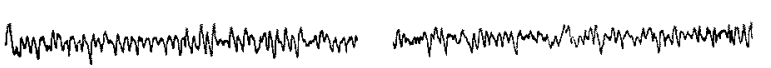
$10 \mathrm{~m}$ $20 \mathrm{~m}$

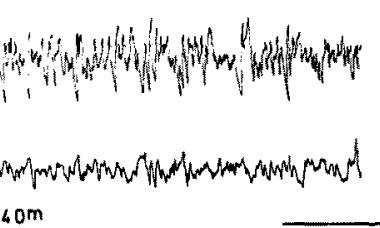

Fig. 13. Effect of imipramine on EEG arousal response induced by physostigmine in the rabbit, A: EEG after i.v. injection of imipramine $5 \mathrm{mg} / \mathrm{kg}$. B: $2 \mathrm{~min}$ after i.v. injection of physostigmine $0.1 \mathrm{mg} / \mathrm{kg}$. C: after $5 \mathrm{~min}$. D: after $10 \mathrm{~min}$. E: after $20 \mathrm{~min}$. F: after $40 \mathrm{~min}$. Imipramine was administered $5 \mathrm{~min}$ before physostigmine injection.

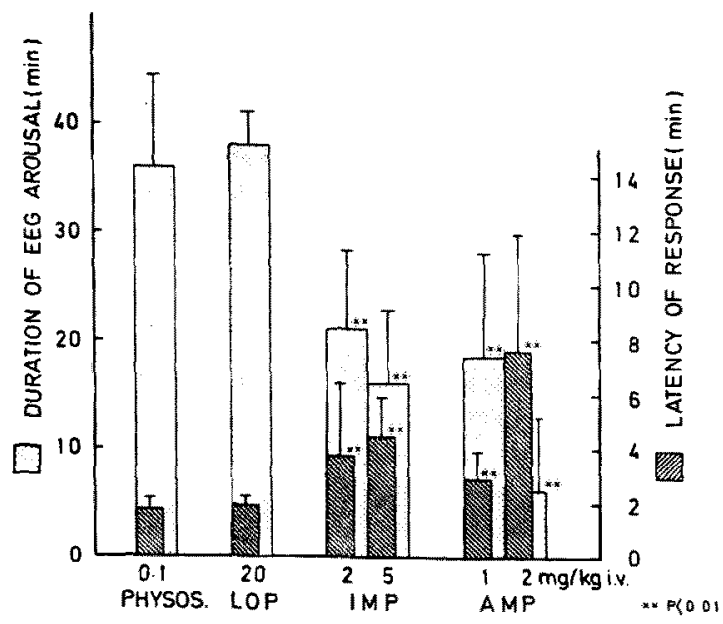

Fig. 14. Effects of tricyclic antidepressants on EEG arousal response induced by physostigmine in the rabbit. PHYSOS: physostigmine, LOP: lopramine, IMP: imipramine, AMP: amitriptyline. The drugs were administered 5 min before physostigmine injection. Vertical scales above each column indicate standard deviations. **: Significant difference vs. the control response at a $1 \%$ level. 
則なパターンを示した．また皮質においてもときどき高電生徐波が混入し，その覚醒ハタターンはかなり不明確で あった，とくに後頭葉皮質ではなかなか低電圧速波が出現しなかった (Fig. 13).

Amitriptyline 1 および $2 \mathrm{mg} / \mathrm{kg}$ の作用は14羽のウサギについて調べた. Amitriptyline $1 \mathrm{mg} / \mathrm{kg}$ 投与後に

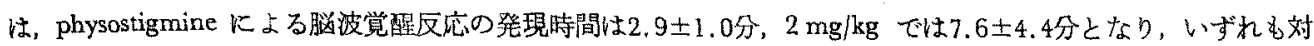

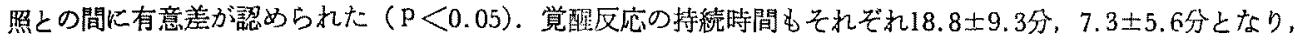
有意に短縮が認められた $(\mathrm{P}<0.005)$ 。また amitriptyline 投与後の覚醒庈志パターンは imipramine の埸合と ほ结同様であり，覚醒反応そのものも皮質脳波にしばしば高電王徐波が混入したり，不鮮明な反応であった。 以上，physostigmineによって誘発される脳波覚醒反応付対する lopramine の作用は imipramine，amitriptyline よりむはるかに弱かった。これらの結果は lopramine の中枢性抗コリン作用がきわめて弱いことを示唆するも のと思われる (Fig. 14).

\section{4. 濑增反応 (recruiting response) におよぼす影㖕}

ウサギの視床内側中心核に $8 \mathrm{~Hz}, 0.1 \mathrm{msec}$ の矩形波刺激を10秒間加文ると，大脳皮質の広範团に，いわゆ る漸增反応 (recruiting response) が誘発される ${ }^{10)}$ 。この反応に対する lopramine の作用を 5 羽のウサギについ て梌討した.

Lopramine 10 20 mg/kg を静脈内注射しても，recruiting response にははとんど認もべき変化はみられな かった (Fig. 15).

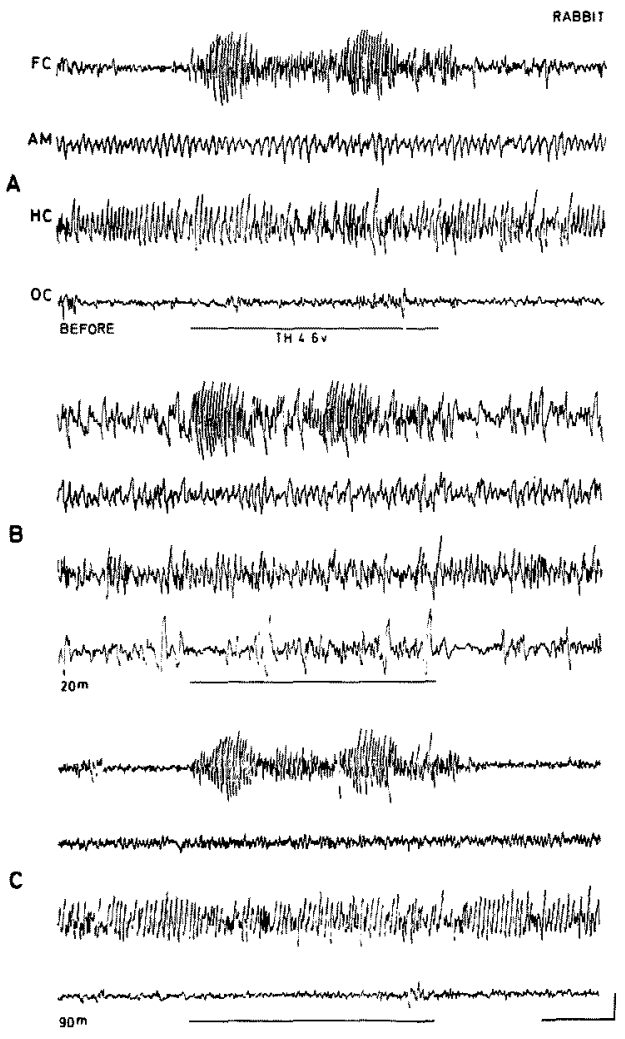

Fig. 15. Effect of lopramine on recruiting response in the rabbit. A: control response B: 20 min after i.v. injection of lopramine $20 \mathrm{mg} / \mathrm{kg}$. C: after $90 \mathrm{~min}$. The centromedian thalamus was stimulated electrically $(8 \mathrm{~Hz}, 0.1 \mathrm{msec}, 4.6 \mathrm{~V})$ at the point indicated by a horizontal line. 


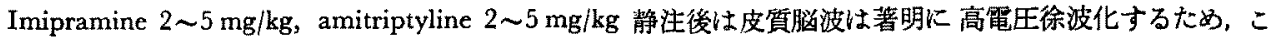
の高雷王徐波に重なって，やや不明確にはなるが，瀄增反応はむしる正常時よりる增強される傾向が諗められた，

\section{5. 大䏚辺緑系後発射におよぼす影整}

大脳辺縁系の海鹂および雇桃核は，電気刺激を加壳ると，刺激終了後しばらくの間接続するいわゆる後発射 (afterdischarges) を誘発することがよく知られている ${ }^{11,12)}$ 。この後発射の発現，持続および他の脳部位への伝幡 波及の状態におよぼす lopramine の作用を imipramine，amitriptyline の作用と比較怢討した，実験に際して は，薬物投与前に 3 回の刺激を行い，每回ほぼ一定した持続の後発射が得られる刺激条件をえらび，これを確認 したのち，薬物の作用を調べた。

Lopramine の作用はのベ10羽のウサギを用いて調べた．Lopramine 5〜10 $\mathrm{mg} / \mathrm{kg} の$ 静注後10〜30分間は海

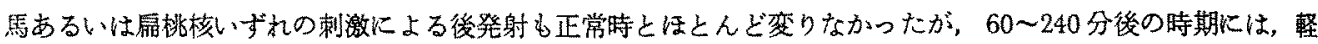
度ながら後発射は增强ざれ，持続時間の延長が認められた (Fig. 16).

Imipramine 5 10 mg/kg では，静注後 10〜30 分頃までは後発射は著明に抑制され，発射の持続は短縮さ れ，例よっては発射が全く発現しないこともあった，投与後60分以上経過すると後発射は急速に回復し，その 後は逆に增强される㑯向を示し，しばしば 2 次発射をおこー列もみられた。

Amitriptyline 2〜 $5 \mathrm{mg} / \mathrm{kg}$ の作用は imipramine とほぼ同様であるが，㣪発射抑制作用は imipramine よ

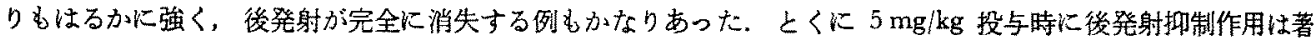

FC

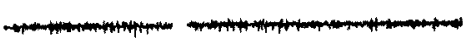

A

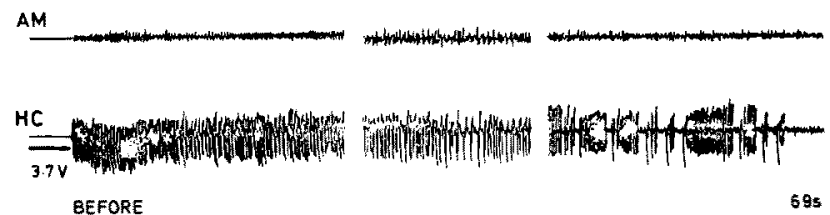

B
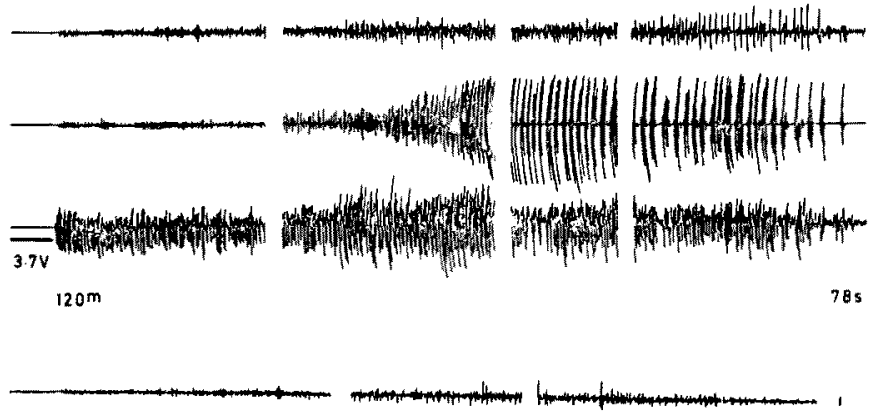

C
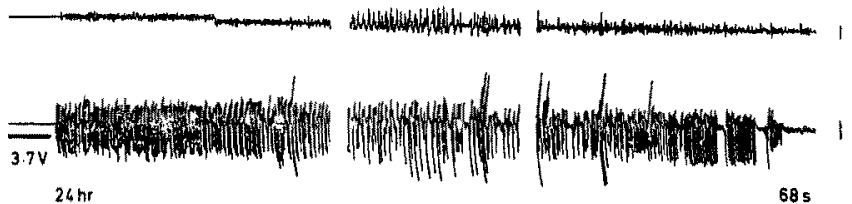

Fig. 16. Effect of lopramine on limbic afterdischarges elicited by hippocampal stimulation in the rabbit. A: control response B: $120 \mathrm{~min}$ after i.v. injection of lopramine 20 $\mathrm{mg} / \mathrm{kg}$. C: after $24 \mathrm{hr}$. The hippocampus was stimulated electrically $(50 \mathrm{~Hz}, 0.2$ msec, $3.7 \mathrm{~V}$ ) at the point indicated by a horizontal line. 

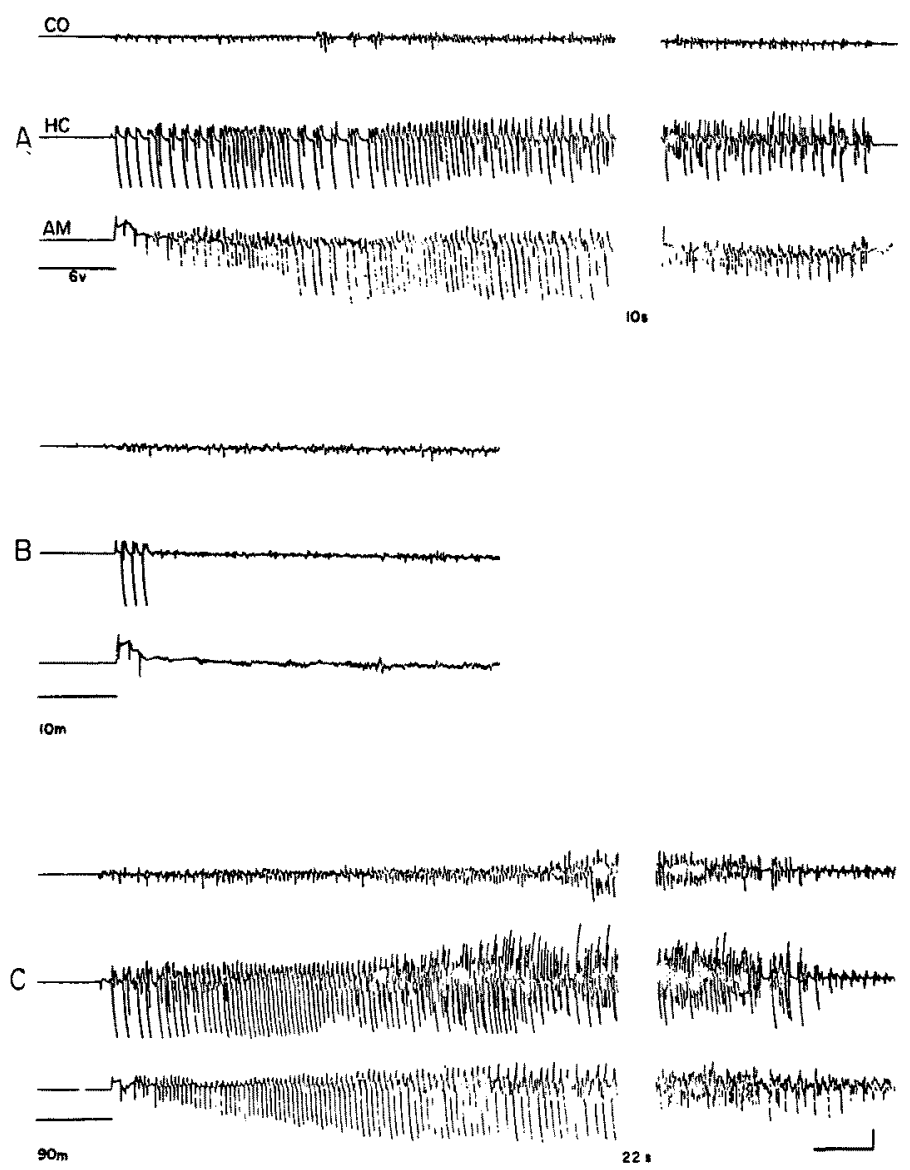

Fig. 17. Effect of amitriptyline on limbic afterdischarges elicited by amygdaloid stimulation in the rabbit. A: control response B: $10 \mathrm{~min}$ after i.v. injection of amitriptyline $2 \mathrm{mg} / \mathrm{kg} \mathrm{C}$ : after $90 \mathrm{~min}$. CO: frontal cortex. The amygdala was stimulated electrically $(50 \mathrm{~Hz}, 0.2 \mathrm{msec}, 6 \mathrm{~V})$ at the point indicated by a horizontal line.

明であった。 amitriptyline の場合も imipramine と同様，投与後60分以上経過すると後発射は急速に回復し， その後は逆熷強される傾向を示したが，その程度は imipramine とほぼ同じであった (Fig. 17).

以上，海馬あるいは扁桃核の電気刺激によって出現する後発射に対して， lopramine は抑制作用を示すこと なく，軽度の增強作用が認められた，Imipramine，amitriptyline は投与後初期には著明な抑制を示し，その後 は逆に堌強を抽こす作用がありここの点 lopramine の作用は，これらの薬物とは異なるものである.

\section{考察}

慢性電極植込みウサギを用いて 行動を観察しながら脳波を測定し， lopramine の作用を調べた 本実験の結 果, $5 \mathrm{mg} / \mathrm{kg}$ 以下の静注では自発脑波に汪とんど変化は認められないが，10 $\mathrm{mg} / \mathrm{kg}$ 以上を用いると，皮質およ び扁桃核脳波は高電圧徐波，海馬では $\theta$ 波の脱同期化が括こり，脳波はいわゆる drowsy pattern を示すよう になる.これに対して imipramine の場合には $1 \mathrm{mg} / \mathrm{kg}$, amitriptyline では $0.5 \mathrm{mg} / \mathrm{kg}$ の小量投与によってす で自発腷波にかなり著明な drowsy pattern が発現し，脳波作用は lopramine よりもはるが強力であり， 持続も長いまた lopramine の場合は大量投与によって脳波が drowsy pattern に変った時です，行動上には 著明な变化は認められず，ごく軽度の鎮静を示すに過なかった。 しかし imipramine および amitriptyline の投 
与では脳波の変化に伴ってウサギは著明な鎮静状態となり，歩行にさいしてはかなりの運動失調が認められる.

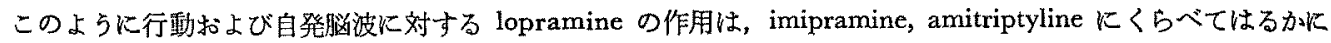
弱いものである.

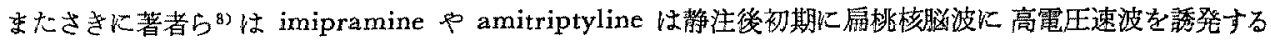
ことを報告したが，本実験でも同梯の作用を認めた．しかし lopramine は初めから扁桃核脳波を高電圧徐波化 するだけで，速波の出現はみられなかった。この点でも lopramine の脳波作用は imipramine, amitriptyline のそれとは異なる。

つぎに音刺激や中脳絪棣体，視床内側中心核，視床下部の電気刺激に対する脳波覚醒反心は，lopramine に

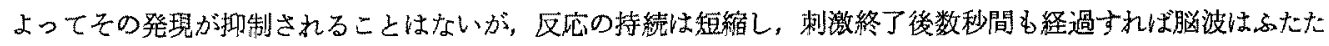
び drowsy pattern にがるよらになる.これに対して imipramine, amitriptyline はいずれの脳波覚醒反応を む著明に抑制し，刺激閥値の上昇を抗こした。

以上， lopramine は自発脳波を drowsy pattern 化する点では imipramine, amitriptyline と類似するが，こ れはごく大量用いてはじめてみられる作用であり，さらに音刺激などの知覚刺激による覚醒反応だけでなく，中 脳網様体，視床内側中心核，視床下部刺激仁上る脳波覚醒反応に対してほとんど抑制作用を示さない点。また扁 挑核脳波に高電圧速波を発現しない点でも，lopramine の作用は imipramine，amitriptyline とは質的に異なる ものである. しかし当教室における行動薬理学的研究では, lopramine は抗 reserpine 作用, methamphetamine やDOPA の作用增強，あるいはラットの mouse-killing behavior の抑制など imipramine や amitriptyline と

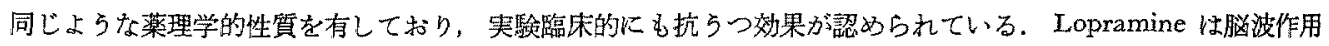

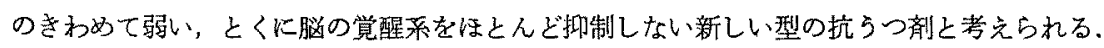

Imipramine を代表とする従来の三環性抗らつ剂は抗コリン作用を有することが知られている。るここで，本 実験ではとくに中枢性抗コリン作用を調べる目的で， cholinesterase 阻害郕である physostigmine によって誘

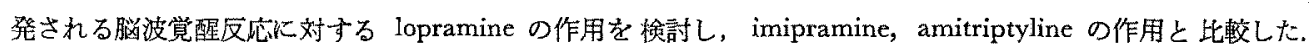
Physostigmine の投与により，大脳皮質に持続的な覚醒波が出現することは Funderburk and Case13), Longo'14), Bradley ${ }^{15)}$ ，Monnier ${ }^{16\rangle}$ らに上って報告されており，この党醒反応は知覚刺激や中脳網様体刺激に上って誘発さ

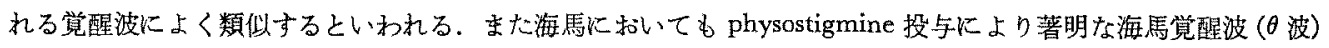
の出現することが知られているが，本実験でも泟活同様の結果であった，Bartolini17)らは physostigmine 投

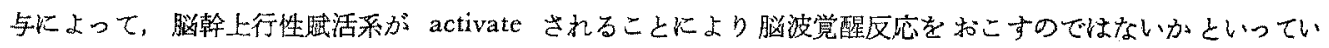

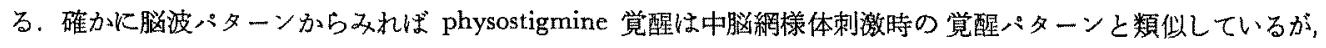
physostigmine 投与時には脳波の覚醒パターンが非常に著明であるにかかわらず，動物が暴れだすよらなことも ほとんどなく，行動上の覚酯の程度は脳波の覚醒の程度と心ずしも平行しない，中脳網様体刺激の場合には脳波 覚醒に平行して行動上の覚醒水準も著明に上昇し，刺激電圧をらょっと高くすると動物はしばしば暴れぞす。 た海馬の $\theta$ 波の出現は physostigmine 覚醒時には非常に著明で，電圧も大きく，中脳網様体刺激時のそれ之は 比べものにならない，さらに，中脳網様体刺激では，刺激電圧がごく高い場合には刺激期間中はむしろ海馬覚醒 波が出現しがたいといら事実もあり，physostigmineによる脳波覚醒反応の出現には中脳網様体の賦活だけでな

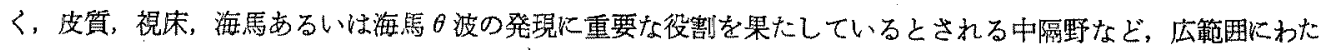
る脳部位の cholinergic mechanism の関与を考克る必要があると思われる。

この physostigmine 党醒に対して，lopramineは $20 \mathrm{mg} / \mathrm{kg}$ の大量でもほとんど影響をおよぼさなかった。 これに対して，imipramine，amitriptyline 投与時には覚醒反応の発現は著明に遅延し，持続時間は短縮した。 た覚醒波が出現してもそれはきわめて不鮮明なものであった．Imipramine，amitriptyline を大量投与した場合 には，海馬の $\theta$ 波が軽度に発現するだけで新皮質脳波は高電压徐波のままで低電圧速波にはならない場合が多 かった.これらの結果は， lopramine が imipramine や amitriptyline とは異なり中权性抗コリン作用を惊と んどもたないことを示唆するものである。当教室に括けるマウスの実験でも， imipramine や amitriptylineが physostigmine の致死作用に対して著明に捛抗するのに対して, lopramine は $1,000 \mathrm{mg} / \mathrm{kg}$ の大量を経口投与し てもまったく拮抗作用はみられなかった．Lopramine には中权性抗コリン作用がないと考えてよいよらである。 


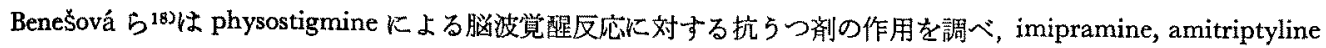
が著明な拮抗作用を有するのに対して，neuroleptica は捛抗作用をまったく示さないことから，これは抗うつ成

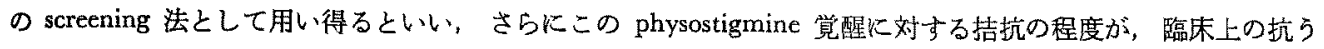
つ効果に比例するといっている. しかし本実験でも明らかなように, lopramineは imipramine と同じ三環性抗 らつ成でありながら physostigmine 覚醒反応に対する搭抗作用を欠如し，しかも行動薬理学的には imipramine や amitriptyline に匹做するような抗らつ剂としての作用特性を有し，臨床的にも抗うつ作用が認められてい る. したがって lopramineの場合には, physostigmine 覚整反応に対する作用と抗うつ作用との平行関保はまっ たく成り立なない，その相関は抗コリン作用を有する抗うつ剂に限っていえることで，普遍化ざれるべき法則で はないと考える，抗コリン作用を欠く lopramine のような抗らつ剂の出現は注目に便する. Lopramine の抗ら つ作用機序に関しては，脳の adrenergic あるいは serotonergic mechanisms がより重要でないかと思われる.

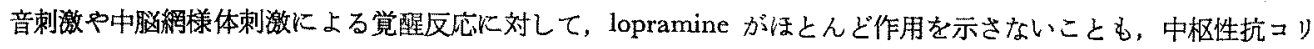
ン作用の欠如と直接関係があるかどうかは不明である. しかし atropine が中脳絧様体刺激による脑波覚醮反応 を著明に抑制するといら報告もあり19 211，lopramine が脳波覚醒反応を抑制しないのは中权性抗コリン作用を欠 くためではないかとも考劣られる。

視床内側中心核の低頻度刺激による漸增反応に対して lopramine はほとんど作用を示さない，したがっ て lopramine は視床内側中心核と皮質の間の反響回路に対して作用しないものと考えられる. Imipramineゃ amitriptyline はこの漸增反応学增強する傾向を示した。これは反響回路に対する直接作用によるとも考えられ るが，この漸增反応は中脳網様体の活動水準が高まっている時には出現しにくくなる㑯向があるので22, これら の薬物が中脳網様体を抑制した結果, 二次的に增強されたのかも知れない、いずれにしろ，この堌强作用は著明 なものではない.

つぎに，海馬あるいは府桃核の電気刺激によって誘発される後発射に対して，lopramine は $20 \mathrm{mg} / \mathrm{kg}$ の 量投与でも抑制作用を示さず，静注後30－60分後頃より後発射はをしろ軽度ながら增強される傾向を示した．こ れに対して imipramine, amitriptyline は投与初期には後発射を著明に抑制し，その後は逆に增強するという2 相性の作用を示した，これは著者らがさきに報告した結果と同様である，後発射に対する抗うつ剂の作用につ

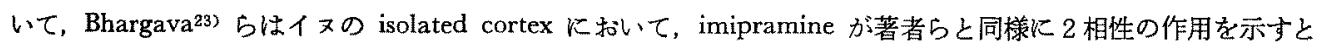
報告しており，またSchmitt ${ }^{24)}$ は扁桃核の後発射は小量 $(1 \sim 2 \mathrm{mg} / \mathrm{kg}) の$ imipramine, amitriptyline により增 強され，大量 $(5 \sim 10 \mathrm{mg} / \mathrm{kg})$ で抑制されるとしている．また笠井25)や金子26)らは imipramine が辺縁系後発射を 抑制するとし，研究者によってその結果は一定していない：これは薬物の投与方法や投与後の時間経過，その他 実験条件の違いも関係するるのと思われる.しかし本実験の結果では， lopramine は imipramine，amitriptyline のよらな2相性の作用を示すこともなく，後発射に対する影響はきわめて軽度であった。これは lopramineが マゥスの pentetrazol けいれんにほとんど作用を示さないといら教室の研究結果とよく一致する.

以上， lopramine の脳波作用は全般的にきわめて弱く，とくに覚醒系に対する作用がほとんどないこと， physostigmine 覚醙反応に対する拮抗作用が全くないこと，さらに大脳辺縁系後発射の抑制作用むない点など, imipramine, amitriptyline の脳波作用とは大いに異なる。これは lopramine が中权性抗コリン作用を欠如する ことと関保があるように思われる.

\section{文献}

1) Siwgrs, B., Freyschuss, U., Hamberger, B., Tuck, D., Marmefors, T. and Sjögvist, F.: Europ. J. clin. Pharmacol. 3, 12 (1970)

2）大原健士郎，笠原洋勇：臨床精神医学 3，97（1974）

3）村陭光邦, 佐藤喜一郎, 望月保則, 菅原道哉, 原俊夫 : 精神医学 16, 409 (1974)

4) 森 温理, 加藤能男, 長岡健太郎: 薬理と治療 12, 642 (1974)

5) ERrksoo, E. and RoHTE, O.: Arzneim.-Forsch. 20, 1561 (1970)

6) 藤原道弘，井上和秀，植木昭和：日薬理誌 70，26§（1974）

7) Sawyer, C. H., Everett, J.W. and Green, J.P.: J. Comp. Neurol. 101, 801 (1954)

8）渡辺繁紀，森本保人，植木昭和：日薬理誌 68，809（1972） 
9) Longo, V. G. and Silverstrim, B.: J. Pharmacol. exp. Ther. 120, 160 (1956)

10) Dempsey, E. W. and Morison, R.S.: Amer. J. Physiol. 131, 718 (1941)

11) Groor, P.: Handbook of Physiology, Neurophysiology, Vol. II, p. 1395, American Physiological Society, Washington, D. C. (1960)

12) GREen, T. D.: Handbook of Phusiology, Neurophysiology, Vol. II, p. 1373, American Physiological Society, Washington, D. C. (1960)

13) Funderburk, W.H. and Case, J.J.: Electroenceph. clin. Neurophysiol. 3, 213 (1951)

14) Longo, V. G.: Experientia 11, 76 (1955)

15) Bradley, P. B. and Elkes, J.: Brain 80, 77 (1957)

16) Monnier, M.: Arch. int. Pharmacodyn. 124, 281 (1960)

17) Bartolin, A., Bartolin, R. and Domino, E. F.: Neuropharmacol. 12, 15 (1973)

18) Benș̌ová, O., Bohdanecky, Z. and Grofová, I.: Int. J. Neuropharmacol. 3, 479 (1964)

19) Bradley, P. B. and KeY, B. J.: Electroenceph. clin. Neurophysiol. 10, 97 (1958)

20) Paul-David, J., Riehl J. L. and Unna, K. R.: J. Pharmacol. exp. Ther. 129, 69 (1960)

21) Longo, V.: Rabbit Brain Research, Vol. 2, p. 41, Elservier, Amsterdam (1962)

22) Verzeano, M., Lindsley, D. B. and Magoun, H. W.: J. Neurophysiol. 16, 183 (1953)

23) Bhargava, K.P., Sinha, J. N. and Tangri, K. K.: Br. J. Pharmacol. Chemother. 27, 468 (1966)

24) Schmrt, H.: International Symposium on Antidepressant Drugs, 1, Milan, Ed. by Garattini, S. and Dukes, M. N. G., p. 104, Excerpta Medica Foundation, Amsterdam (1967)

25）笠井 勉：精神神経誌 71，859（1969）

26）金子仁郎，蕧川泰夫，志水 彰，福井昭平，日高靖彦：譄上神経 12，698（1960）

\begin{abstract}
Shigenori WATANABE, Hiromu KAWASAKI and Showa UEKI (Department of Pharmacology, Faculty of Pharmaceutical Sciences, Kyushu University, Fukuoka 812, Japan). Electroencephalographic effects of lopramine in rabbits. Folia pharmacol. japon. 72, 153 168 (1976).

Electroencephalographic (EEG) effects of lopramine, a new antidepressant, were investigated in rabbits with chronic electrode implants, and compared with those of imipramine and amitriptyline. All drugs were administered i.v. Lopramine $(10,20 \mathrm{mg} / \mathrm{kg})$ induced a drowsy pattern of spontaneous EEG consisted of high voltage slow waves in the cortex and amygdala, and desynchronization of hippocampal thetha waves. Imipramine and amitriptyline $(1-5 \mathrm{mg} / \mathrm{kg})$ also elicited similar EEG changes but were much more potent than lopramine in this effect. Lopramine $(10,20 \mathrm{mg} / \mathrm{kg})$ failed to suppress the EEG arousal responses induced by not only auditory stimulation but also electrical stimulation of the mesencephalic reticular formation, centromedian thalamus and posterior hypothalamus, whereas imipramine and amitriptyline ( $1 \sim 5 \mathrm{mg} / \mathrm{kg})$ markedly inhibited these responses. The EEG arousal response induced by i.v. injection of physostigmine $0.1 \mathrm{mg} / \mathrm{kg}$ showed no change after lopramine $(20 \mathrm{mg} / \mathrm{kg})$, while the response was significantly suppressed by imipramine $(2,5 \mathrm{mg} / \mathrm{kg})$ and amitriptyline $(1,2 \mathrm{mg} / \mathrm{kg})$. Lopramine showed no effect on the recruiting response induced by electrical stimulation $(8 \mathrm{~Hz})$ of the centromedian thalamus and slightly enhanced the limbic afterdischarges elicited by either hippocampal or amygdaloid stimulation, while imipramine $(2,5 \mathrm{mg} / \mathrm{kg})$ and amitriptyline $(1-5 \mathrm{mg} / \mathrm{kg}$ ) caused an initial depression followed by sustained enhancement of these afterdischarges. These results demonstrate lopramine to be an antidepressant of a new type which has no effect on the ascending reticular activating system and no central anticholinergic action.
\end{abstract}

